\title{
Anti-IgE treatment, airway inflammation and remodelling in severe allergic asthma: current knowledge and future perspectives
}

\author{
Konstantinos Samitas ${ }^{1,2}$, Vasiliki Delimpoura ${ }^{1}$, Eleftherios Zervas ${ }^{1}$ \\ and Mina Gaga ${ }^{1}$
}

\begin{abstract}
Affiliations: ${ }^{17 t h}$ Respiratory Dept and Asthma Centre, Athens Chest Hospital "Sotiria", Athens, Greece. ${ }^{2}$ Cellular Immunology Laboratory, Division of Cell Biology, Centre for Basic Research, Biomedical Research Foundation of the Academy of Athens, Athens, Greece.
\end{abstract}

Correspondence: Mina Gaga, 7th Respiratory Dept and Asthma Centre, Athens Chest Hospital "Sotiria", Athens 11527, Greece. E-mail: minagagađyahoo.com

ABSTRACT Asthma is a disorder of the airways involving various inflammatory cells and mediators and characterised by bronchial hyperresponsiveness, chronic inflammation and structural alterations in the airways, also known as remodelling. IgE is an important mediator of allergic reactions and has a central role in allergic asthma pathophysiology, as it is implicated in both the early and late phase allergic response. Moreover, clinical and mechanistic evidence has lately emerged, implicating IgE in the development of airway remodelling. The use of monoclonal antibodies targeting IgE, such as omalizumab, has proven very effective in improving respiratory symptoms and quality of life, while reducing asthma exacerbations, emergency room visits and the use of systemic corticosteroids in allergic severe asthma. These effects are believed to be mainly mediated by omalizumab's inhibitory effect on the initiation and further propagation of the allergic inflammation cascade. However, there is evidence to suggest that anti-IgE treatment remains effective long after it has been discontinued. In part, these findings could be attributed to the possible ameliorating effects of anti-IgE treatment on airway remodelling. In this review, we discuss recent findings supporting the notion that anti-IgE treatment modulates the complex immune responses that manifest clinically as asthma and ameliorates airway remodelling changes often observed in allergic severe asthma phenotypes.

@ERSpublications

Anti-IgE treatment suppresses the inflammatory airway response and markers of remodelling in allergic asthma http://ow.ly/Som4i

\section{Introduction}

Asthma is a disorder of the airways involving multiple inflammatory cells and mediators [1]. Clinically, it is characterised by symptoms and bronchial hyperresponsiveness and pathologically by chronic inflammation and structural alterations in the airways, also referred to as remodelling. IgE is an important mediator of allergic reactions, including allergic asthma, and has a central role in asthma-related symptoms, airway inflammation and, possibly, airway remodelling $[2,3]$.

In patients with allergic asthma, exposure to allergens to which they are sensitised results in the rapid release of pro-inflammatory mediators that cause immediate contraction of airway smooth muscle and increased mucus production and the symptoms of the early allergic/asthmatic reaction, that is, wheezing, shortness of breath, chest tightness and cough. Moreover, these pro-inflammatory mediators and chemokines attract and activate inflammatory cells, which release more pro-inflammatory mediators. This

Received: Feb 162015 | Accepted after revision: March 052015

Conflict of interest: Disclosures can be found alongside the online version of this article at err.ersjournals.com

Provenance: Submitted article, peer reviewed.

Copyright OERS 2015. ERR articles are open access and distributed under the terms of the Creative Commons Attribution Non-Commercial Licence 4.0. 
slower reaction that takes hours to develop, known as the late allergic/asthmatic response, is characterised by inflammatory infiltration and bronchoconstriction and leads to tissue remodelling.

Remodelling of the airways is a central feature of asthma, especially severe asthma; it can lead to fixed airway obstruction and refractoriness to treatment [4-6]. Most elements of the airway wall are implicated in the structural changes observed during remodelling. Epithelial shedding, reticular basement membrane (RBM) thickening, goblet cell hyperplasia, smooth muscle hyperplasia and hypertrophy, subepithelial fibrosis and angiogenesis are the most prominent findings usually observed in remodelled airways (fig. 1). Although the exact underlying mechanisms of airway remodelling still elude us, the existence of chronic persistent inflammation, involving longstanding exposure of the airways to a variety of environmental agents, cells and mediators, is generally considered a prerequisite [7-9], and IgE is central to the initiation and persistence of this inflammation $[2,10]$. Therapeutic agents with the potential to block the allergic cascade at an early stage, such as omalizumab, may potentially also attenuate airway remodelling, a possibility also supported by evidence suggesting that long-term anti-IgE treatment remains effective long after it has been discontinued [11-13].

In this review, we discuss recent findings supporting the notion that anti-IgE treatment modulates the complex immune responses that manifest clinically as asthma and reverses airway remodelling changes often observed in severe allergic asthma.

\section{$\lg \mathrm{E}$}

IgE exists as monomers consisting of two heavy chains ( $\varepsilon$-chain) and two light chains, with the $\varepsilon$-chain containing four constant domains (Cع1-Ce4) [14]. Although the main function of IgE is to provide immunity against parasites such as parasitic worms, with the practical elimination of parasites in most of the developed world, IgE is today mainly linked with allergic reactions, playing an essential role in type I hypersensitivity. These reactions include allergic asthma, allergic rhinitis and sinusitis, food allergy and some types of chronic urticaria as well as anaphylactic reactions to certain drugs, allergens and foods.

\section{IgE receptors}

There are two kinds of IgE receptors: the low-affinity IgE receptor (FceRII; CD23) and the high-affinity IgE receptor (FceRI) [14]. The high-affinity IgE receptors are expressed on the surface of mast cells and basophils as tetramers $(\alpha \beta \gamma 2)$ and on antigen-presenting cells as trimers ( $\alpha \gamma 2)$, at much lower levels [15]. The density of FceRI expression on human basophils and mast cells correlates directly with IgE levels. Moreover, the expression of the $\beta$-chain in FceRI in mast cells and basophils is upregulated with increased FceRI expression and amplifies signalling through the receptors. The binding of IgE to the receptor stabilises the receptor on the cell surface [16].

The low-affinity IgE receptor is expressed on B-cells and other haematopoietic cells (T-cells, Langerhans cells, macrophages, monocytes, eosinophils and platelets). The expression of CD23 is upregulated by $\operatorname{IgE}$ and interleukin (IL)-4 and CD23 activation mediates IgE regulation, differentiation of B-cells, activation of monocytes and antigen presentation $[16,17]$.

\section{IgE and the allergic cascade}

IgE has a central role in the pathophysiology of allergic inflammation and asthma. Upon first allergen exposure, antigen-presenting cells sensitise naïve T-cells and direct their development towards the T-helper (Th)2 phenotype. IL-4 and IL-13 are produced, increasing FceRII expression and triggering the relevant
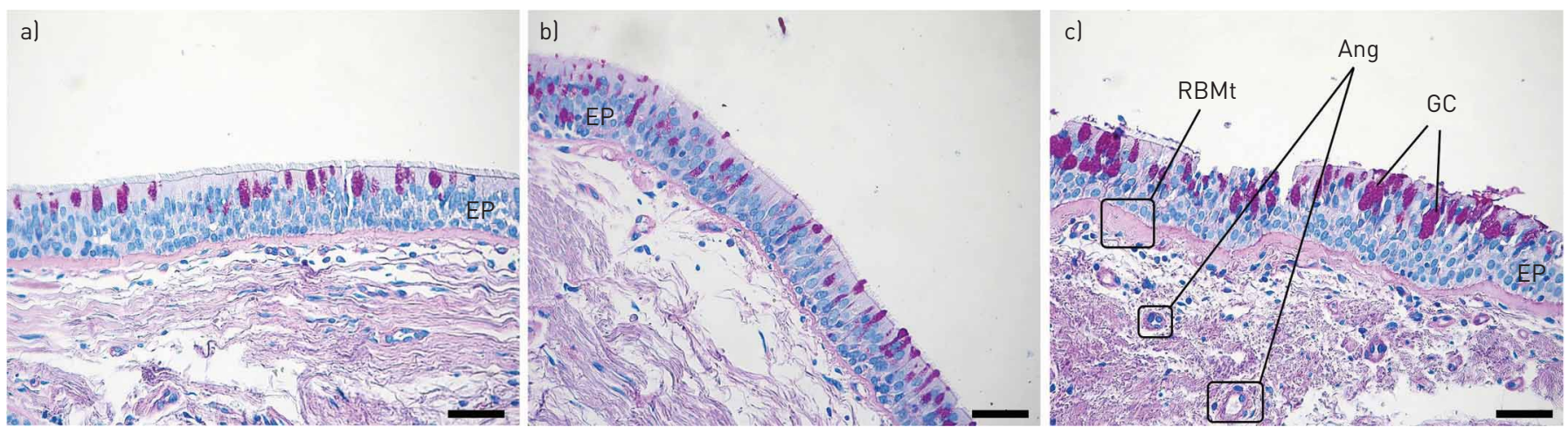

FIGURE 1 Microphotographs ( $\times 20)$ of endobronchial biopsies from a) healthy control, b) mildly asthmatic and c) severe asthmatic airways demonstrating increased thickness of the basement membrane (haematoxylin-eosin stain) and goblet cell (GC) hyperplasia (periodic acid-Schiff stain) as asthma severity increases. EP: epithelium; RBMt: reticular basement membrane; Ang: angiogenesis. Scale bars $=50 \mu \mathrm{m}$. 
B-cells to produce allergen-specific IgE $[18,19]$. During their progression to IgE-secreting plasma cells, B-lymphocytes also express membrane-bound IgE, which assists in antigen processing and signal transduction. Secreted IgE binds to the FceRI on mast cells and basophils and sensitises them to the allergen. Subsequent allergen exposure leads to cross-linking of membrane-bound IgE in mast cells and basophils, inducing degranulation and the release of histamine, tryptase, cysteine-leukotrienes and platelet-activating factors. These mediators have an almost immediate oedematous and bronchoconstrictive effect, key symptoms of the early allergic response $[16,20]$.

The events driven by the preformed mediators of mast cells and basophils during the early response lead to the production and release of cytokines and chemokines such as IL-3, IL-4, IL-5, Il-13, CC chemokine ligand-5 and granulocyte-macrophage colony-stimulating factor, which recruit neutrophils, eosinophils and basophils, T-cells and macrophages to the site of inflammation [16, 20]. This process, also known as the late allergic/asthmatic response, takes hours to develop and promotes mucus hypersecretion, airway inflammation and hyperresponsiveness. The importance of IgE during late-phase reactions and later establishment of chronic allergic airway inflammation has been shown experimentally in mice lacking the FceRI $\alpha$ chain, which, compared to wild-type mice, show diminished airway inflammation in an asthma model [21].

\section{IgE and airway remodelling}

The activation of the allergic cascade by IgE, under constant allergen stimulation, leads to the establishment of chronic allergic inflammation in the airways of asthmatic patients, with IgE being a key element of the vicious circle that maintains it. Cytokines produced during the late phase and subsequent chronic inflammation stage have been directly associated with the induction of airway remodelling, indirectly implicating IgE in the process. Asthmatic airways are dominated by eosinophils, mast cells and Th2 cells that produce various cytokines, such as IL-4, IL-5 and IL-13, which participate in the perpetuation of airway inflammation and the induction of airway remodelling [22]. IL-4 stimulates synthesis and release of IgE from $\mathrm{B}$-cells and is suggested to be a mediator of airway remodelling by increasing synthesis of $\alpha$-smooth muscle actin and collagen III [23, 24]. IL-13 induces eosinophilic airway inflammation and promotes mucus metaplasia, subepithelial fibrosis and airway remodelling $[25,26]$. Eosinophils also produce and express many fibrogenic factors, particularly transforming growth factor (TGF)- $\beta 1$ [27]. Finally, other cytokines with increased expression in the airways of asthmatics, such as osteopontin, are closely associated with airway remodelling $[28,29]$. It is therefore conceivable that IgE may indirectly contribute to airway remodelling by increasing the production and release of the aforementioned inflammatory mediators.

However, preliminary experimental data suggest that IgE might also be directly associated with airway remodelling (table 1) [30-33]. This would be in accordance with previous studies dissociating chronic inflammation from airway structural changes. Increased RBM thickness has been reported as early as 1 year of age in preschool-aged wheezers [34] and even within 8 days in response to inhaled allergens or to cholinergic stimuli in mild asthmatics [35]. Given the inability of the damaged bronchial epithelium to act as a barrier in severe asthmatics, it is possible for both allergens and IgE to penetrate and directly reach resident tissue-forming cells. Moreover, recent observations suggest that antigen-specific IgE can be produced locally in the bronchial mucosa $[36,37]$. Notably, the bronchial epithelial cells of asthmatics express the high-affinity receptor for IgE [38]. Human airway smooth muscle (HASM) cells also express both low- and high-affinity IgE receptors, through which IgE can modulate cellular contraction and inflammatory mediator synthesis, such as IL-4, IL-5 and IL-13 [30, 31]. Interestingly, it was recently demonstrated that IgE stimulation of HASM cells isolated from asthmatic patients in vitro increased cell proliferation and extracellular matrix and collagen deposition in a dose-dependent manner [32, 33].

\section{Anti-IgE treatment}

Anti-IgE treatment can be mediated by any form of biological medication targeting the synthesis or signalling pathway of IgE, either directly or indirectly, and several such agents are currently under investigation. Lumiliximab (IDEC-152) is a primatised monoclonal antibody against FceRII that has already been shown to block IgE synthesis in human B-cells and reduce serum IgE levels [39, 40]. Ligelizumab (QGE031), a humanised monoclonal IgG1א antibody with a high avidity for IgE, was also recently evaluated regarding its pharmacokinetics, pharmacodynamics and safety [41]. Monoclonal antibody-12 is another promising anti-human $\operatorname{IgE}$ antibody that may prove useful for the extracorporeal depletion of IgE and IgE-bearing cells from peripheral blood [42]. However, omalizumab is the only biological anti-IgE agent currently licensed for use in humans.

Omalizumab is a recombinant DNA-derived humanised $\operatorname{IgG}_{1}$ monoclonal antibody produced by Chinese hamster ovary cells. It was originally constructed as a murine antibody selectively binding to human $\operatorname{IgE}$ [43]. Omalizumab was approved by the US (Food and Drug Administration) in 2003 and by the European Union (European Medicines Agency) in 2005 as an add-on treatment for patients aged $>12$ years with 
TABLE 1 The main findings of important recent clinical and experimental studies directly associating IgE or anti-lgE treatment with features of airway remodelling

\begin{tabular}{|c|c|c|c|}
\hline First author [ref.] & Year & Study design & Main findings \\
\hline GounNi [30] & 2005 & $\begin{array}{l}\text { Experimental study } \\
\text { In vitro (HASM cells from atopic } \\
\text { asthmatics, } n=6 \text { ) }\end{array}$ & $\begin{array}{l}\text { HASM cells express FceRI (high-affinity IgE receptor) } \\
\text { IgE stimulation triggered HASM contraction and IL-4, } \\
\text { IL-5, IL-13 and eotaxin release }\end{array}$ \\
\hline KANG $[70]$ & 2010 & $\begin{array}{l}\text { Experimental study } \\
\text { Murine model of chronic asthma } \\
\text { Three groups (control, OVA and } \\
\text { omalizumab + OVA) }\end{array}$ & $\begin{array}{l}\text { Omalizumab decreased airway hyperresponsiveness, } \\
\text { BALF inflammatory cell counts, BALF IL-5 and IL-13 } \\
\text { levels, peribronchial collagen III/V, hydroxyproline } \\
\text { and } \alpha \text {-smooth muscle actin } \\
\text { BALF TGF- } \beta \text { and activin-A levels were not significantly } \\
\text { altered in the omalizumab group (although both } \\
\text { tended to increase) }\end{array}$ \\
\hline Rотн [31] & 2010 & $\begin{array}{l}\text { Experimental study } \\
\text { In vitro (primary HASM cells) } \\
\text { Three groups (allergic asthma, COPD } \\
\quad \text { and control, } \mathrm{n}=6 \text { each) }\end{array}$ & $\begin{array}{l}\text { IgE stimulation increased IL-6, IL- } 8 \text { and TNF- } \alpha \text { mRNA } \\
\text { synthesis and secretion by HASM cells in all groups } \\
\text { Omalizumab inhibited IgE-stimulated cytokine secretion } \\
\text { in a dose-dependent fashion }\end{array}$ \\
\hline Hoshino [65] & 2012 & $\begin{array}{l}\text { Clinical study } \\
30 \text { severely allergic asthmatics } \\
\text { Randomised 1:1 (omalizumab versus } \\
\text { conventional therapy for } 16 \text { weeks) }\end{array}$ & 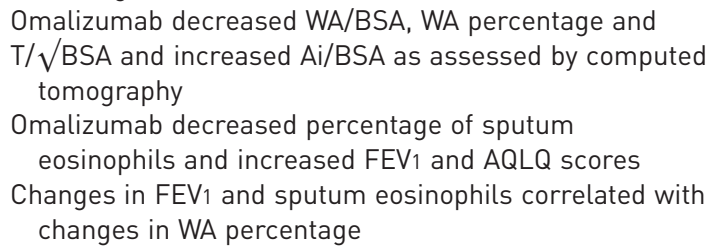 \\
\hline Rотн [32] & 2013 & $\begin{array}{l}\text { Experimental study } \\
\text { In vitro (primary HASM cells) } \\
\text { Two groups (allergic asthmatics and } \\
\quad \text { nonasthmatics, both } \mathrm{n}=8 \text { ) }\end{array}$ & $\begin{array}{l}\text { IgE increased HASM cell proliferation and extracellular } \\
\text { matrix and collagen deposition in a dose-dependent } \\
\text { manner } \\
\text { IgE effects were more prominent in asthmatic tissue } \\
\text { Pre-incubation with omalizumab prevented all } \\
\text { remodelling effects }\end{array}$ \\
\hline
\end{tabular}

HASM: human airway smooth muscle; IL: interleukin; OVA: ovalbumin; BALF: bronchoalveolar lavage fluid; TGF: transforming growth factor; COPD: chronic obstructive pulmonary diesase; TNF: tumour necrosis factor; RBM: reticular basement membrane; WA: wall area; BSA: body

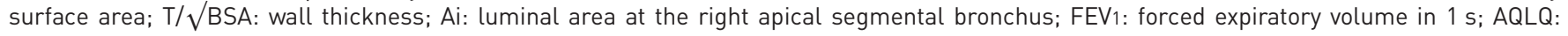
asthma quality of life questionnaire; MAPK: mitogen-activated protein kinase; STAT: signal transducer and activator of transcription; FeNO50: exhaled nitric oxide fraction at $50 \mathrm{~mL} \cdot \mathrm{s}^{-1}$.

severe persistent allergic asthma who have a positive skin test or in vitro reactivity to a perennial aeroallergen and who have reduced lung function (forced expiratory volume in $1 \mathrm{~s}(\mathrm{FEV} 1)<80 \%$ ) as well as frequent daytime symptoms or night-time awakenings and who have had multiple documented severe asthma exacerbations despite daily high-dose inhaled corticosteroids, plus a long-acting inhaled $\beta_{2}$-agonist. In 2009, it also received approval in Europe for treating patients aged 6-12 years with the same indications without the requirement of reduced lung function.

\section{Omalizumab: how does it work?}

The obvious target of any monoclonal antibody against IgE would be circulating (free) IgE. The challenge in creating such an antibody is to avoid cross-linking with cell membrane FceRI-bound IgE, which would 
inevitably lead to mast cell and basophil activation and subsequent release of their preformed pro-inflammatory mediators. The design of omalizumab allows it to inhibit the binding of free IgE to the FceRI by attaching itself to the same antigenic epitope on IgE [44-46]. Conversely, when IgE is bound to the FceRI on the cell membrane, this epitope is sterically hindered by the receptor and not accessible to omalizumab, therefore blocking its binding and averting any undesirable effects.

Another mechanism by which omalizumab exerts its functions, initially unforeseen by its developers, is its ability to gradually downregulate FceRI expression on basophils and mast cells [47-49]. This effect is of great importance, as it renders these cells less sensitive to allergen stimulation, leading to a reduction of eosinophilic influx and activation. This negative effect on FceRI expression was also demonstrated on dendritic cells [50], directly affecting their ability to skew naïve T-cells towards the Th2 pathway and reducing Th2 cytokine release and subsequent inflammation [51]. Interestingly, omalizumab was recently shown to target membrane IgE-bearing B-cells by directly inducing a state of anergy, in which B-cells become unresponsive to antigenic stimuli [52].

All the aforementioned effects of omalizumab have been well documented at a clinical level. In a study of 15 patients allergic to house dust mite, treatment with anti-IgE decreased serum free IgE levels by $99 \%$ and FceRI density on basophils by $97 \%$. Furthermore, a 100 -fold increase in antigen dose was needed in order to produce a skin prick test response equal to pretreatment levels [48]. In another study including 24 patients with allergen-induced rhinitis, free IgE levels decreased by $96 \%$ and FceRI expression on basophils decreased by $75 \%$ after omalizumab treatment [53]. Reduction in surface IgE and FceRI expression was also demonstrated in subjects with cat allergy [54]. Moreover, in a recent study of 15 asthmatics who received omalizumab for 12 weeks, basophil FceRI expression was decreased by $96 \%$ while at the same time IL-4, IL-8 and IL-13 FceRI-mediated production decreased [55].

Clinical data are also available regarding the effects of omalizumab on dendritic cells. Treating patients allergic to cats with omalizumab led to a reduction of FceRI on blood plasmacytoid dendritic cells and myeloid dendritic cells by $66 \%$ and $48 \%$, respectively, while IgE expression was also reduced by $>95 \%$ [51]. Meanwhile, a modest reduction was also observed in dendritic cell dependent T-cell proliferation to cat allergen after treatment with omalizumab [51]. In another study involving patients with severe allergic asthma, treatment with omalizumab for 16 weeks reduced FceRI expression on basophils and plasmacytoid dendritic cells by $82 \%$ and $44 \%$, respectively [56].

So omalizumab not only reduces circulating free IgE levels but it reduces the expression of its receptors on both effector and antigen-presenting cells, lowering or blocking allergic reactions. In addition, there are several reports suggesting a role for IgE in nonatopic asthma, and some proof-of-concept studies and case reports have also suggested an efficacy of anti-IgE therapy in so-called intrinsic asthma, indicating that anti-IgE treatment may also modulate innate immunity [57].

\section{Omalizumab and airway inflammation}

Several clinical controlled studies, as well as real-life experience studies, have demonstrated the safety and efficacy of omalizumab in reducing asthma-related symptoms, corticosteroid use, exacerbation rates and emergency visits, while improving patients' quality of life in inadequately controlled patients with severe allergic asthma [58-61].

These beneficial clinical effects of omalizumab are a result of its profound anti-inflammatory impact on the airways of patients with severe allergic asthma, mediated by the mechanisms mentioned earlier. Numerous studies have shown the effect of omalizumab in the airways of allergic asthmatics. In a hallmark study by DJukANović et al. [62], inflammatory cells were evaluated in induced sputum and bronchial biopsies in 45 steroid-naïve mild/moderate allergic asthmatic patients after 16 weeks of treatment with omalizumab or placebo. Treatment with omalizumab resulted in reduction of sputum and airway eosinophilia. Moreover, omalizumab was associated with a marked decrease in epithelial and subepithelial cells expressing FceRI and cell-surface IL-4, as well as submucosal B-cells, $\mathrm{CD}^{+}, \mathrm{CD}^{+}$and $\mathrm{CD} 8^{+}$T-lymphocytes [62]. In a randomised double-blind placebo-controlled study involving 25 allergic asthmatics, VAN RENSEN et al. [63] provided additional evidence that sputum and airway eosinophils, as well as FceRI ${ }^{+}$and $\mathrm{CD}^{+}$cells, are reduced after omalizumab treatment. A few more recent studies reported similar findings [64-66], possibly associated with decreased expression of IL-4 and IL-5 [62, 67].

\section{Omalizumab: a possible modulator of airway remodelling?}

By inhibiting IgE-mediated responses, omalizumab disrupts a key element of the allergic inflammatory cascade. Given the crucial role of allergic airway inflammation in the occurrence of structural airway changes, it is conceivable that omalizumab may indirectly contribute to decreased airway remodelling in patients with allergic asthma by inhibiting the expression and production of pro-inflammatory cytokines 
associated with remodelling, such as TGF- $\beta$ and endothelin-1 $[68,69]$. Limited evidence is currently available to support this notion [3]; however, a few preliminary experimental and clinical studies in the past few years have implicated anti-IgE treatment with the amelioration of airway remodelling parameters, such as airway wall thickening and smooth muscle hyperplasia (table 1).

The first set of data came from an experimental study using a murine model of chronic allergic airway inflammation based on ovalbumin sensitisation and subsequent periodic intranasal re-exposure for 3 months [70]. The authors showed that omalizumab decreased airway hyperresponsiveness and inflammatory cell counts, IL-5 and IL-13 levels in bronchoalveolar lavage fluid. Importantly, omalizumab also decreased markers of remodelling, such as peribronchial collagen III/V deposition, hydroxyproline and $\alpha$-smooth muscle actin.

Driven by the previous findings on murine models, Rотн and colleagues [31,32] engaged in a series of in vitro experiments utilising primary HASM cells. Initially, they isolated and cultured HASM cells bearing IgE receptors from healthy controls and patients with chronic obstructive pulmonary disease and allergic asthma ( $n=6$ each) [31]. IgE stimulation was reported to increase IL-6, IL-8 and tumour necrosis factor- $\alpha$ mRNA synthesis and corresponding protein secretion in all groups, while omalizumab inhibited cytokine secretion in a dose-dependent manner [31]. The authors continued experimenting with HASM cells isolated from asthmatics and control subjects, demonstrating that IgE induced greater HASM cell proliferation as well as extracellular matrix (ECM), collagen type I, III, VII and fibronectin deposition in asthmatics. Pre-incubation with omalizumab inhibited all remodelling effects [32]. The researchers also found that IgE stimulates collagen type-I and type-VII deposition through IgE receptor-I and extracellular signal-regulated kinase (ERK) $1 / 2$ and mitogen-activated protein kinase (MAPK), but the proliferation and the deposition of collagen type-III and fibronectin involves both IgE receptors as well as ERK1/2 and p38 MAPK [32]. ReDHu and Gounni [33] later on showed that IgE-induced proliferation of HASM cells is mediated via the MAPK, Akt and signal transducer and activator of transcription-3 signalling pathways.

Based on the results of the previous in vitro studies, two clinical studies set out to investigate the potential effects of omalizumab on the airway wall using computed tomography imaging in a limited number of patients with allergic asthma [65, 66]. The study by Hoshino and OHTAwa [65] was the first to examine the effects of conventional treatment with $(n=14)$ or without $(n=16)$ omalizumab in 30 severely asthmatic patients. Airway wall area (WA) corrected for body surface area (BSA), percentage WA, wall thickness $(\mathrm{T}) / \sqrt{ }$ BSA and luminal area/BSA were significantly decreased after 16 weeks' treatment with omalizumab. In the same study, the researchers found a significant reduction in induced sputum eosinophilia from $6 \%$ to $2 \%(\mathrm{p}<0.001)$ and a significant increase in FEV1 after omalizumab treatment, with both changes significantly correlating with changes in WA\% [65]. Similar findings were later reported by TAJIRI et al. [71].

The aforementioned radiological findings were recently corroborated by histopathological observations of Riccio et al. [64] on bronchial biopsy samples obtained from 11 patients with severe persistent allergic asthma before and after 1 year of treatment with omalizumab. The authors observed a significant reduction in RBM thickness after treatment with omalizumab, accompanied by a marked but not statistically significant reduction in eosinophil infiltration. No correlation was found between reduction in thickness of RBM and reduction in eosinophilic infiltration, possibly attributed to the limited number of patients. Interestingly, a proteomic analysis of bronchial biopsies was also performed by the same group on eight severe asthmatics before and after treatment with omalizumab for 1 year [72]. The authors divided the patients in the basis of whether they responded to treatment and performed a cluster analysis of baseline proteomes to pinpoint differences between groups on the protein level. It was demonstrated that administration of omalizumab downregulated bronchial smooth muscle proteins [72]. Moreover, among all ECM proteins, galectin-3 was the most reliable and predictive biomarker of airway remodelling modulation by omalizumab.

\section{Conclusion}

The introduction of biological agents, such as anti-IgE and anti-IL-5 for the treatment of allergic asthma and other allergic diseases, has opened exciting new fields for clinicians to explore [73, 74]. Anti-IgE treatment, as represented by omalizumab, has proven very effective in improving clinical parameters in patients with noncontrolled severe allergic asthma by directly interrupting the vicious circle of inflammation mediated by IgE hypersensitivity. Furthermore, preliminary data support the possibility that anti-IgE treatment may also be a disease modifying pharmacological intervention by directly or indirectly preventing or reversing airway remodelling changes previously considered to be rather permanent. The ongoing EXCELS study (Evaluating Clinical Effectiveness and Long-term Safety in Patients with Moderate-to-Severe Asthma) will shed more information on the natural history of severe asthma and the efficacy of omalizumab [75]. Moreover, there is increasing interest in developing new monoclonal antibodies presenting higher avidity for IgE, such as ligelizumab and lumiliximab, and the ability to interact with low-affinity IgE receptors [76]. Further studies are needed to fully elucidate the exact mechanisms through which anti-IgE treatment benefits patients with severe allergic asthma. 


\section{References}

1 Global Initiative for Asthma (GINA). Global Strategy for Asthma Management and Prevention, 2014. www.ginasthma.org/ Date last accessed: January 2015. Date last updated: May 2014.

2 Holgate S, Casale T, Wenzel S, et al. The anti-inflammatory effects of omalizumab confirm the central role of IgE in allergic inflammation. J Allergy Clin Immunol 2005; 115: 459-465.

3 Rabe KF, Calhoun WJ, Smith N, et al. Can anti-IgE therapy prevent airway remodeling in allergic asthma? Allergy 2011; 66: 1142-1151.

4 James A. Airway remodeling in asthma. Curr Opin Pulm Med 2005; 11: 1-6.

5 Pascual RM, Peters SP. Airway remodeling contributes to the progressive loss of lung function in asthma: an overview. J Allergy Clin Immunol 2005; 116: 477-486.

6 James AL, Wenzel S. Clinical relevance of airway remodelling in airway diseases. Eur Respir J 2007; 30: 134-155.

7 Hirota N, Martin JG. Mechanisms of airway remodeling. Chest 2013; 144: 1026-1032.

8 Pain $\mathrm{M}$, Bermudez $\mathrm{O}$, Lacoste $\mathrm{P}$, et al. Tissue remodelling in chronic bronchial diseases: from the epithelial to mesenchymal phenotype. Eur Respir Rev 2014; 23: 118-130.

9 Shifren A, Witt C, Christie C, et al. Mechanisms of remodeling in asthmatic airways. J Allergy 2012; 2012: 316049.

10 Humbert M, Busse W, Hanania NA, et al. Omalizumab in asthma: an update on recent developments. J Allergy Clin Immunol Pract 2014; 2: 525-536.

11 Nopp A, Johansson SG, Adédoyin J, et al. After 6 years with Xolair; a 3-year withdrawal follow-up. Allergy 2010; 65: 56-60.

12 Solèr M. Omalizumab for severe allergic asthma: 7 years and open questions. Respiration 2014; 88: 158-161.

13 Molimard M, Mala L, Bourdeix I, et al. Observational study in severe asthmatic patients after discontinuation of omalizumab for good asthma control. Respir Med 2014; 108: 571-576.

14 Holowka D, Sil D, Torigoe C, et al. Insights into immunoglobulin E receptor signaling from structurally defined ligands. Immunol Rev 2007; 217: 269-279.

15 MacGlashan D, Jr. IgE receptor and signal transduction in mast cells and basophils. Curr Opin Immunol 2008; 20 : 717-723.

16 Stone KD, Prussin C, Metcalfe DD. IgE, mast cells, basophils, and eosinophils. J Allergy Clin Immunol 2010; 125: Suppl. 2, S73-S80.

17 Rosenwasser LJ, Meng J. Anti-CD23. Clin Rev Allergy Immunol 2005; 29: 61-72.

18 Punnonen J, Aversa G, Cocks BG, et al. Interleukin 13 induces interleukin 4-independent IgG4 and IgE synthesis and CD23 expression by human B cells. Proc Natl Acad Sci USA 1993; 90: 3730-3734.

19 Samitas K, Lötvall J, Bossios A. B cells: from early development to regulating allergic diseases. Arch Immunol Ther Exp 2010; 58: 209-225.

20 Galli SJ, Tsai M. IgE and mast cells in allergic disease. Nat Med 2012; 18: 693-704.

21 Mayr SI, Zuberi RI, Zhang M, et al. IgE-dependent mast cell activation potentiates airway responses in murine asthma models. J Immunol 2002; 169: 2061-2068.

22 Cohn L, Elias JA, Chupp GL. Asthma: mechanisms of disease persistence and progression. Annu Rev Immunol 2004; 22: 789-815.

23 Batra V, Musani AI, Hastie AT, et al. Bronchoalveolar lavage fluid concentrations of transforming growth factor (TGF)- $\beta 1$, TGF- $\beta 2$, interleukin (IL)- 4 and IL- 13 after segmental allergen challenge and their effects on $\alpha$-smooth muscle actin and collagen III synthesis by primary human lung fibroblasts. Clin Exp Allergy 2004; 34: 437-444.

24 Novak N, Bieber T. Allergic and nonallergic forms of atopic diseases. J Allergy Clin Immunol 2003; 112: 252-262.

25 Doherty T, Broide D. Cytokines and growth factors in airway remodeling in asthma. Curr Opin Immunol 2007; 19: $676-680$.

26 Zhu Z, Homer RJ, Wang Z, et al. Pulmonary expression of interleukin-13 causes inflammation, mucus hypersecretion, subepithelial fibrosis, physiologic abnormalities, and eotaxin production. J Clin Invest 1999; 103: 779-788.

27 Kay AB, Phipps S, Robinson DS. A role for eosinophils in airway remodelling in asthma. Trends Immunol 2004; 25: $477-482$.

28 Samitas K, Zervas E, Vittorakis S, et al. Osteopontin expression and relation to disease severity in human asthma. Eur Respir J 2011; 37: 331-341.

29 Samitas K, Zervas E, Xanthou G, et al. Osteopontin is increased in the bronchoalveolar lavage fluid and bronchial tissue of smoking asthmatics. Cytokine 2013; 61: 713-715.

30 Gounni AS, Wellemans V, Yang J, et al. Human airway smooth muscle cells express the high affinity receptor for IgE (FceRI): a critical role of FceRI in human airway smooth muscle cell function. J Immunol 2005; 175 : 2613-2621.

31 Roth M, Tamm M. The effects of omalizumab on IgE-induced cytokine synthesis by asthmatic airway smooth muscle cells. Ann Allergy Asthma Immunol 2010; 104: 152-160.

32 Roth $\mathrm{M}$, Zhong J, Zumkeller $\mathrm{C}$, et al. The role of IgE-receptors in IgE-dependent airway smooth muscle cell remodelling. PLoS One 2013; 8: e56015.

33 Redhu NS, Gounni AS. The high affinity IgE receptor (FceRI) expression and function in airway smooth muscle. Pulm Pharmacol Ther 2013; 26: 86-94.

34 Saglani S, Payne DN, Zhu J, et al. Early detection of airway wall remodeling and eosinophilic inflammation in preschool wheezers. Am J Respir Crit Care Med 2007; 176: 858-864.

35 Grainge CL, Lau LC, Ward JA, et al. Effect of bronchoconstriction on airway remodeling in asthma. N Engl J Med 2011; 364: 2006-2015.

36 Takhar P, Corrigan CJ, Smurthwaite L, et al. Class switch recombination to IgE in the bronchial mucosa of atopic and nonatopic patients with asthma. J Allergy Clin Immunol 2007; 119: 213-218.

37 Galli SJ, Tsai M. IgE and mast cells in allergic disease. Nat Med 2012; 18: 693-704.

38 Campbell AM, Vachier I, Chanez P, et al. Expression of the high-affinity receptor for IgE on bronchial epithelial cells of asthmatics. Am J Respir Cell Mol Biol 1998; 19: 92-97.

39 Nakamura T, Kloetzer WS, Brams P, et al. In vitro IgE inhibition in B cells by anti-CD23 monoclonal antibodies is functionally dependent on the immunoglobulin Fc domain. Int J Immunopharmacol 2000; 22: 131-141.

40 Rosenwasser LJ, Busse WW, Lizambri RG, et al. Allergic asthma and an anti-CD23 mAb (IDEC-152): results of a phase I, single-dose, dose-escalating clinical trial. J Allergy Clin Immunol 2003; 112: 563-570. 
41 Arm JP, Bottoli I, Skerjanec A, et al. Pharmacokinetics, pharmacodynamics and safety of QGE031 (ligelizumab), a novel high-affinity anti-IgE antibody, in atopic subjects. Clin Exp Allergy 2014; 44: 1371-1385.

42 Laffer S, Lupinek C, Rauter I, et al. A high-affinity monoclonal anti-IgE antibody for depletion of IgE and IgE-bearing cells. Allergy 2008; 63: 695-702.

43 Presta LG, Lahr SJ, Shields RL, et al. Humanization of an antibody directed against IgE. J Immunol 1993; 151: 2623-2632.

44 Chang TW. The pharmacological basis of anti-IgE therapy. Nat Biotechnol 2000; 18: 157-162.

45 Chang TW, Shiung YY. Anti-IgE as a mast cell-stabilizing therapeutic agent. J Allergy Clin Immunol 2006; 117: 1203-1212.

46 Chang TW, Wu PC, Hsu CL, et al. Anti-IgE antibodies for the treatment of IgE-mediated allergic diseases. Adv Immunol 2007; 93: 63-119.

47 MacGlashan D, Jr. Therapeutic efficacy of omalizumab. J Allergy Clin Immunol 2009; 123: 114-115.

48 MacGlashan DW, Jr, Bochner BS, Adelman DC, et al. Down-regulation of FceRI expression on human basophils during in vivo treatment of atopic patients with anti-IgE antibody. J Immunol 1997; 158: 1438-1445.

49 MacGlashan DW, Jr, Savage JH, Wood RA, et al. Suppression of the basophil response to allergen during treatment with omalizumab is dependent on 2 competing factors. J Allergy Clin Immunol 2012; 130: 1130-1135.

50 Prussin C, Griffith DT, Boesel KM, et al. Omalizumab treatment downregulates dendritic cell FceRI expression. J Allergy Clin Immunol 2003; 112: 1147-1154.

51 Schroeder JT, Bieneman AP, Chichester KL, et al. Decreases in human dendritic cell-dependent $\mathrm{T}_{\mathrm{H}} 2$-like responses after acute in vivo IgE neutralization. J Allergy Clin Immunol 2010; 125: 896-901.

52 Chan MA, Gigliotti NM, Dotson AL, et al. Omalizumab may decrease IgE synthesis by targeting membrane $\operatorname{IgE}^{+}$ human B cells. Clin Transl Allergy 2013; 3: 29.

53 Lin H, Boesel KM, Griffith DT, et al. Omalizumab rapidly decreases nasal allergic response and FceRI on basophils. J Allergy Clin Immunol 2004; 113: 297-302.

54 Eckman JA, Sterba PM, Kelly D, et al. Effects of omalizumab on basophil and mast cell responses using an intranasal cat allergen challenge. J Allergy Clin Immunol 2010; 125: 889-895.

55 Oliver JM, Tarleton CA, Gilmartin L, et al. Reduced FceRI-mediated release of asthma-promoting cytokines and chemokines from human basophils during omalizumab therapy. Int Arch Allergy Immunol 2010; 151: 275-284

56 Chanez P, Contin-Bordes C, Garcia G, et al. Omalizumab-induced decrease of FceRI expression in patients with severe allergic asthma. Respir Med 2010; 104: 1608-1617.

57 Lommatzsch M, Korn S, Buhl R, et al. Against all odds: anti-IgE for intrinsic asthma? Thorax 2014; 69: 94-96.

58 Brusselle G, Michils A, Louis R, et al. "Real-life" effectiveness of omalizumab in patients with severe persistent allergic asthma: the PERSIST study. Respir Med 2009; 103: 1633-1642.

59 Buhl R. Anti-IgE: lessons from clinical trials in patients with severe allergic asthma symptomatic despite optimised therapy. Eur Respir Rev 2007; 16: 73-77.

60 D'Amato G, Bucchioni E, Oldani V, et al. Treating moderate-to-severe allergic asthma with a recombinant humanized anti-IgE monoclonal antibody (omalizumab). Treat Respir Med 2006; 5: 393-398.

61 Humbert M, Beasley R, Ayres J, et al. Benefits of omalizumab as add-on therapy in patients with severe persistent asthma who are inadequately controlled despite best available therapy (GINA 2002 step 4 treatment): INNOVATE. Allergy 2005; 60: 309-316.

62 Djukanović R, Wilson SJ, Kraft M, et al. Effects of treatment with anti-immunoglobulin E antibody omalizumab on airway inflammation in allergic asthma. Am J Respir Crit Care Med 2004; 170: 583-593.

63 van Rensen EL, Evertse CE, van Schadewijk WA, et al. Eosinophils in bronchial mucosa of asthmatics after allergen challenge: effect of anti-IgE treatment. Allergy 2009; 64: 72-80.

64 Riccio AM, Dal Negro RW, Micheletto C, et al. Omalizumab modulates bronchial reticular basement membrane thickness and eosinophil infiltration in severe persistent allergic asthma patients. Int J Immunopathol Pharmacol 2012; 25: 475-484.

65 Hoshino M, Ohtawa J. Effects of adding omalizumab, an anti-immunoglobulin E antibody, on airway wall thickening in asthma. Respiration 2012; 83: 520-528.

66 Tajiri T, Niimi A, Matsumoto H, et al. Comprehensive efficacy of omalizumab for severe refractory asthma: a time-series observational study. Ann Allergy Asthma Immunol 2014; 113: 470-475.

67 Takaku Y, Soma T, Nishihara F, et al. Omalizumab attenuates airway inflammation and interleukin-5 production by mononuclear cells in patients with severe allergic asthma. Int Arch Allergy Immunol 2013; 161: Suppl. 2, $107-117$

68 Huang YC, Leyko B, Frieri M. Effects of omalizumab and budesonide on markers of inflammation in human bronchial epithelial cells. Ann Allergy Asthma Immunol 2005; 95: 443-451.

69 Zietkowski Z, Skiepko R, Tomasiak-Lozowska MM, et al. Anti-IgE therapy with omalizumab decreases endothelin- 1 in exhaled breath condensate of patients with severe persistent allergic asthma. Respiration 2010; 80: $534-542$.

70 Kang JY, Kim JW, Kim JS, et al. Inhibitory effects of anti-immunoglobulin E antibodies on airway remodeling in a murine model of chronic asthma. J Asthma 2010; 47: 374-380.

71 Tajiri T, Matsumoto $\mathrm{H}$, Hiraumi $\mathrm{H}$, et al. Efficacy of omalizumab in eosinophilic chronic rhinosinusitis patients with asthma. Ann Allergy Asthma Immunol 2013; 110: 387-388.

72 Mauri P, Riccio AM, Rossi R, et al. Proteomics of bronchial biopsies: galectin-3 as a predictive biomarker of airway remodelling modulation in omalizumab-treated severe asthma patients. Immunol Lett 2014; 162: 2-10.

73 Pelaia G, Vatrella A, Maselli R. The potential of biologics for the treatment of asthma. Nat Rev Drug Discov 2012; 11: 958-972.

74 Samitas K, Rådinger M, Bossios A. Current update on eosinophilic lung diseases and anti-IL-5 treatment. Recent Pat Antiinfect Drug Discov 2011; 6: 189-205.

75 Long AA, Fish JE, Rahmaoui A, et al. Baseline characteristics of patients enrolled in EXCELS: a cohort study. Ann Allergy Asthma Immunol 2009; 103: 212-219.

76 Menzella F, Lusuardi M, Galeone C, et al. Tailored therapy for severe asthma. Multidiscip Respir Med 2015; $10: 1$. 